\title{
E-Learning and Digital Classroom Solutions in CBSE Schools: A Study of factors that determine the effective knowledge delivery by teachers at secondary level
}

\author{
R Sugant, Dr. SandhyaAnvekar, \\ Research Scholar, Jain University, Bangalore \\ Professor, Department of Management Studies, Visvesvaraya Technological University, Bangalore
}

\begin{abstract}
In today's digital era, e-learning and digital classroom solutions are changing the way the subjects are taught in private schools, providing for standardization and enhanced knowledge delivery. A few large companies in India have implemented E learning and digital classroom solutions in India in over 30,000 private schools. The private schools in India are facing acute shortage of good teachers, thanks to the growth in private sector job opportunities and poor salary and job insecurity in private schools. The schools have to compromise and manage with teachers of varying quality and standards. Against this declining standard of teachers, can elearning and digital classroom solutions help in ensuring effective knowledge delivery to students. This paper will specifically look at effective knowledge delivery through e-learning and digital classroom solutions by teachers at secondary level CBSE (Central Board of Secondary Education) schools in Bangalore. The research is based on two key hypotheses viz., e-Learning and digital classroom solutions help in effective knowledge delivery; e-Learning and digital classroom solutions help the teachers at secondary level in CBSE schools enhance quality of teaching. The research assesses the schools that have adopted e-learning and digital classroom solutions in Bangalore in terms of whether these solutions help in effective knowledge delivery at schools. The study also evaluates the factors of e-learning and digital classroom solutions that help the teachers in enhancing their quality of teaching.
\end{abstract}

\section{Introduction}

India has a plethora of school education boards including central boards like Central Board of Secondary Education (CBSE), Indian Council of Secondary Education (ICSE) and state boards. Of all the boards, CBSE is gaining more importance due to presence of its schools pan India and also the educational standards the board maintains. Though the CBSE board was established in 1929, it was reconstituted in its present form in 1962. Though one of the core objectives was be responsive to the educational needs of those students whose parents were employed in the Central Government and had frequently transferable jobs, today the board caters to the aspirations of the present day Indian parents(children) to have standardized and quality education irrespective of the state they live in. The jurisdiction of CBSE board extends beyond India and schools affiliated to CBSE are now found in other countries including countries in Middle East, Africa and South East Asia. CBSE is the largest board of secondary education in India and from an affiliation of 309 schools in 1962 the Board today has over 15,000 schools affiliated from India and 24 other countries.

India has over 1 million schools [CLSA Indian Education, 2008] that are recognized by the government. Though the government has been constantly increasing the funding for school education, the government and public schooling system has not been able to fulfill the needs of the growing population. Also thanks to the bureaucracy and the systemic inefficiency, the funds allocated do not reach the beneficiary. This results in poor infrastructure, inadequate teachers, poor enrolments and high percentage of drop outs from the government schools. Another lacuna in the government school system is their focus on vernacular language as the medium of instruction, whereas post liberalization, the aspirations of the poor, lower middle and middle class has grown and they too would want their children to be educated in English medium schools.

This has resulted in burgeoning of private schools across the country. Though the number of schools has increased phenomenally, there are quite a many challenges and complexities that the school system in India has to encounter: school teachers and leaders need to-

- Acquire skills in using technology

- Implement effective pedagogy to leverage technological advances

- Create better learning environment and enable effective learning outcomes.

Literature review also shows that there are multiple boards to which the schools can affiliate themselves - CBSE/ CBSE-I/ ICSE/ State Boards. On an all India basis, there are 26 Boards of Education. 
- $\quad$ Another major problem is high amount of drop-outs: It has been found that $16 \%$ of students drop out of Class 1-4 and 43\% Class 5-8 and 68\% in Class 9-12 [CLSA Indian Education, 2008].

- $\quad$ The cost of education in private schools is very high resulting in Indians spending about $9 \%$ of their income on education which is highest among the BRIC countries : the corresponding figures are $6 \%$ for China, $4 \%$ for Brazil and 2\% for Russia [Credit Suisse Emerging Consumer Survey, 2012]

- $\quad$ The varying standards of evaluation of different state boards resulting in some states always declaring a very high students' pass percentage and some very low.

- With the current focus on engineering and commerce courses at the graduate level, students' qualifying with pure sciences graduation has come down drastically and hence there is a serious paucity of teachers with science/ mathematics background.

- With the economy opening up, jobs in the private sector has become very attractive with their higher salaries and hence candidates opting for teaching jobs have come down, further aggravating the problem of getting qualified teachers. This has resulted in a high teacher student ratio, the national average being 1:46, the consequence of which is poor learning outcome.

\section{Digital Classroom Solution [DCS]}

For the schools to remain relevant and grow, newer learning approaches need to be implemented. School teachers and leaders need to adopt technology to overcome the challenges in teaching and academic delivery. The schools started adopting computer based training in 1990s with companies producing basic multimedia content in CD ROMs. The post liberalization and the IT penetration of 1990s and in this decade saw significant growth in schools adopting E learning. The past 8 years saw emergence of many private players such as Educomp Solutions, HCL, NIIT etc. in the school e learning segment. These companies adopted a blended learning method instead of adopting pure e-learning method which helped them to overcome the poor/ non availability of high speed internet. The Digital Classroom Solution (DCS) as was implemented by these companies include computer, projector, interactive white board and multimedia content with features like assessments, lesson plan tools etc.

The digital classroom space in private schools has seen intense competition in the past three years and the market is widely divided and fragmented. The following companies with the national presence are competing for a market share, apart from a host of smaller regional players:

\begin{tabular}{|l|l|}
\hline Product Brand & Company \\
\hline Smartclass & Educomp Solutions \\
\hline Digiclass & Pearson Education \\
\hline Digischool & HCL Learning \\
\hline Teach Next & Next Education \\
\hline SmartLearnClass & Extra Marks Education \\
\hline Classteacher & Shaper Technologies \\
\hline Nguru & NIIT \\
\hline Class Edge & Tata Interactive Solutions \\
\hline
\end{tabular}

\section{Statement of Problem}

One of the vision statements of CBSE is to "work towards evolving a learning process and environment, which empowers the future citizens to become global leader in the emerging knowledge society". Keeping in line with the vision, the Board has been encouraging the affiliated schools to adopt technology for learning. The early adopters of Digital Classroom Solutions in India are CBSE schools.

The schools adopt DCS for various reasons

- As a tool for improving the teaching quality;

- $\quad$ As a tool by the management to market the schools;

- $\quad$ As a tool to overcome the lack of quality teachers.

The focus of the present research is to establish the impact of DCS on knowledge delivery and quality of teaching in CBSE schools in Bangalore.

\section{Research Gap}

Unlike E-Learning, in which lot of research has been done, data on the impact of digital learning solutions, as has been implemented in Indian schools is largely unavailable. It is estimated that over 30,000 schools in India have implemented DCS, but no structured research has been taken up to assess the impact of digital learning solutions on knowledge delivery, knowledge enhancement, quality of teaching etc. 


\section{Research Objectives}

The study was focused on 60 CBSE schools in Bangalore.

The main objectives of the study were-

1. To ascertain the impact of digital classrooms on effective knowledge delivery.

2. To ascertain the impact of DCS on quality of teaching

\section{Hypotheses}

The following hypotheses were postulated and tested with respect to usage of Digital Classroom solutions:

H1: DCS improve knowledge delivery by teachers.

H2: DCS enhance quality of teaching.

\section{Research Methodology}

For the purpose of research, the following broad variables related to effective knowledge delivery and quality of teaching were identified and analyzed.

Knowledge delivery variables:

- $\quad$ Attention of children in class

- Creating excitement about learning

- Conceptual understanding

- $\quad$ Improvement in Average marks scored

- $\quad$ Ability to learn faster

- Improved concentration of children

- $\quad$ Better class participation by children

- Classroom behavior of children

- Ability of children to retain concepts better

- $\quad$ Thinking and problem solving skills of children have improved

Quality of teachingvariables:

- Increase in productivity of teachers

- Increase in confidence of teachers

- Enhancement of teachers' knowledge

- $\quad$ Makes teaching easier

- $\quad$ Better relationship and rapport with children

- $\quad$ Better discipline in the class

- $\quad$ Ability to complete lessons on time

- $\quad$ Better impact with the children

- $\quad$ Better impact with the management

- Improvement in teaching skills

Primary data were collected from teachers of CBSE schools in Bangalore. The questionnaire was structured in such a way as to map the total experience of teachers, experience in using DCS and the variables related to knowledge delivery and quality of teaching.

Sample size:60 samples were selected among the teachers from different CBSE schools in Bangalore.

Sampling method:Simple random sampling was adopted for selecting the respondent from the total population. Data Analysis:Data were analyzed using statistical tools like frequency. Hypothesis were tested using T-test, Chi Square test and cross tab.

\section{Data Analysis \& Interpretation}

\section{Variables under Knowledge Delivery}

Descriptive Statistics

\begin{tabular}{|l|r|r|r|r|r|}
\hline & $\mathrm{N}$ & \multicolumn{1}{|c|}{ Minimum } & Maximum & \multicolumn{1}{c|}{ Mean } & \multicolumn{1}{c|}{ Std. Deviation } \\
\hline Children Attentive in Class & 61 & 3.00 & 5.00 & 4.2459 & .53714 \\
Children Excited & 61 & 3.00 & 5.00 & 4.3607 & .57830 \\
Conceptual Understanding & 61 & 3.00 & 5.00 & 4.4918 & .53613 \\
Improvement In Average Marks & 61 & 2.00 & 5.00 & 3.8689 & .67021 \\
Faster Learning & 61 & 3.00 & 5.00 & 4.1639 & .55318 \\
Concentration & 61 & 3.00 & 5.00 & 3.9836 & .56249 \\
Better Participation & 61 & 3.00 & 5.00 & 4.2459 & .56733 \\
Classroom Behaviour & 61 & 2.00 & 5.00 & 3.8361 & .77847 \\
Concepts Retention & 61 & 3.00 & 5.00 & 4.3607 & .63332 \\
Problem Solving Skills & 61 & 1.00 & 5.00 & 3.9672 & .68233 \\
Valid N (listwise) & 61 & & & & \\
\hline
\end{tabular}


From the above table, it is inferred that, majority of the respondents are positive towards the variables under 'Knowledge delivery'.

The summary rating by teachers of the variables of 'knowledge delivery' with respect to impact as a result of DCS as below:

\begin{tabular}{|c|c|c|c|}
\hline Variable & Agree (\%) & $\begin{array}{l}\text { Strongly } \\
\text { Agree (\%) }\end{array}$ & $\begin{array}{l}\text { Total \% } \\
\text { Agreeing }\end{array}$ \\
\hline Children are able to understand the concepts better & 47.5 & 50.8 & 98.3 \\
\hline Children are more attentive in class & 65.6 & 29.5 & 95.1 \\
\hline Children are excited about learning & 54.1 & 41 & 95.1 \\
\hline Ensures better participation by children in the class & 62.3 & 31.1 & 93.4 \\
\hline Children are able to learn faster & 67.2 & 24.6 & 91.8 \\
\hline Children are able to retain and remember concepts better & 47.5 & 44.3 & 91.8 \\
\hline The concentration of children has improved & 68.9 & 14.8 & 83.7 \\
\hline Thinking and problem solving skills of children have improved & 67.2 & 16.4 & 83.6 \\
\hline Average marks scored by children in exams have improved & 68.9 & 11.5 & 80.4 \\
\hline Classroom behavior of children has improved & 57.4 & 16.4 & 73.8 \\
\hline
\end{tabular}

It could be inferred that among the 10 variables, the following 3 variables are having the maximum impact as a result of DCS:

- Understanding of concepts

- $\quad$ Attention in class

- Excitement about learning

It could be inferred that among the 10 variables, though majority respondents agree to the positive impact, comparatively, the following 4 variables are having the minimum impact as a result of DCS:

- Classroom behavior;

- $\quad$ Average marks scored;

- Improvement in problem solving skills;

- Concentration of children.

\section{Variables under Quality of Teaching}

\begin{tabular}{|l|r|r|r|r|r|}
\hline \multicolumn{2}{|c|}{ Descriptive Statistics } \\
\hline Increased Productivity & $\mathrm{N}$ & Minimum & \multicolumn{1}{c|}{ Maximum } & \multicolumn{1}{c|}{ Mean } & \multicolumn{1}{c|}{ Std. Deviation } \\
Increased Confidence & 61 & 3.00 & 5.00 & 4.1803 & .64571 \\
Enhancement of Knowledge & 61 & 3.00 & 5.00 & 4.1475 & .54271 \\
Easy Teaching & 61 & 2.00 & 5.00 & 4.2295 & .66817 \\
Rapport with Children & 61 & 3.00 & 5.00 & 4.1967 & .65370 \\
Better class Discipline & 61 & 2.00 & 5.00 & 3.9836 & .69503 \\
On time Class Completion & 61 & 2.00 & 5.00 & 3.9016 & .70012 \\
Better Impact with Children & 61 & 2.00 & 5.00 & 4.0492 & .71708 \\
Better Impact with Management & 61 & 3.00 & 5.00 & 4.2295 & .52894 \\
Improved Teaching Skills & 61 & 2.00 & 5.00 & 3.9836 & .78511 \\
Valid N (listwise) & 61 & 3.00 & 5.00 & 4.1311 & .59091 \\
\hline
\end{tabular}

From the above table, it is inferred that, majority of the respondents are positive towards the variables under 'Quality of Teaching'

The summary rating by teachers of the variables of 'quality of teaching' with respect to impact as a result of DCS as below:

\begin{tabular}{|c|c|c|c|}
\hline Variable & Agree (\%) & $\begin{array}{l}\text { Strongly } \\
\text { Agree (\%) }\end{array}$ & $\begin{array}{l}\text { Total \% } \\
\text { Agreeing }\end{array}$ \\
\hline Helps in creating better impact with the children & 67.2 & 27.9 & 95.1 \\
\hline Helps in increasing my confidence & 68.9 & 23 & 91.9 \\
\hline Helps in enhancing my knowledge & 55.7 & 34.4 & 90.1 \\
\hline Has improved my teaching skills & 63.9 & 24.6 & 88.5 \\
\hline Makes teaching easier & 54.1 & 32.8 & 86.9 \\
\hline Helps in increasing my productivity & 55.7 & 31.1 & 86.8 \\
\hline Helps in completing my lessons on time & 59 & 24.6 & 83.6 \\
\hline Helps better relationship and rapport with children & 62.3 & 19.7 & 82 \\
\hline Helps in creating better impact with the management & 59 & 23 & 82 \\
\hline Helps in ensuring better discipline in the class & 60.7 & 16.4 & 77.1 \\
\hline
\end{tabular}


It could be inferred that among the 10 variables, the following 3 variables are having the maximum impact as a result of DCS:

- $\quad$ Creating better impact with children;

- Increase in teachers' confidence;

- $\quad$ Enhancing knowledge of teachers.

It could be inferred that among the 10 variables, though majority respondents agree to the positive impact, comparatively, the following 3 variables are having the minimum impact as a result of DCS:

- Ensuring classroom discipline;

- $\quad$ Creating impact with management;

- Classroom discipline.

Testing of Hypotheses:

H1:Digital Classroom Solutions improve knowledge delivery by teachers.

DCS Usage Years * Knowledge Delivery Cross Tabulation

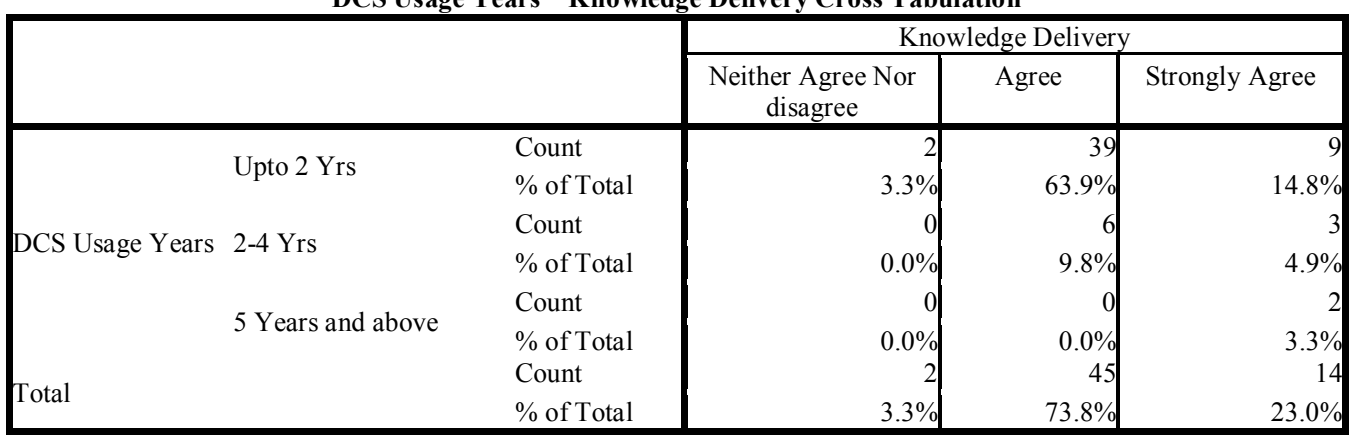

From the above cross tab table it is inferred that, $96.8 \%$ of the respondents agrees that digitalclassroom solutions have improved knowledge delivery and hence the hypothesis is accepted.

\begin{tabular}{|l|r|r|r|}
\hline & Chi-Square Tests \\
\hline Pearson Chi-Square & Value & df & Asymp. Sig. (2-sided) \\
Likelihood Ratio & $8.228^{2}$ & 4 & .084 \\
Linear-by-Linear Association & 7.682 & 4 & .104 \\
N of Valid Cases & 6.102 & 1 & .014 \\
\hline
\end{tabular}

The chi-square value is more than 5 and hence the hypothesis is accepted

H2: Digital Classroom solutions enhance quality of teaching.

\section{DCS Usage Years * Quality of Teaching Crosstabulation}

\begin{tabular}{|c|c|c|c|c|c|}
\hline & & & \multicolumn{3}{|c|}{ Quality of Teaching } \\
\hline & & & $\begin{array}{c}\text { Neither Agree Nor } \\
\text { disagree }\end{array}$ & Agree & Strongly Agree \\
\hline \multirow{6}{*}{ DCS Usage Years } & \multirow{2}{*}{ Upto 2 Yrs } & Count & 6 & 33 & 11 \\
\hline & & $\%$ of Total & $9.8 \%$ & $54.1 \%$ & $18.0 \%$ \\
\hline & \multirow{2}{*}{$2-4$ Yrs } & Count & 0 & 7 & 2 \\
\hline & & $\%$ of Total & $0.0 \%$ & $11.5 \%$ & $3.3 \%$ \\
\hline & \multirow{4}{*}{5 Years and above } & Count & 0 & 0 & 2 \\
\hline & & $\%$ of Total & $0.0 \%$ & $0.0 \%$ & $3.3 \%$ \\
\hline \multirow{2}{*}{ Total } & & Count & & & \\
\hline & & $\%$ of Total & $9.8 \%$ & $65.6 \%$ & $24.6 \%$ \\
\hline
\end{tabular}

From the above cross tab table it is inferred that, $90 \%$ of the respondents agrees that digital classroom solution has helped in improving quality of teaching and hence the hypothesis is accepted.

\begin{tabular}{|c|c|c|c|}
\hline \multicolumn{4}{|c|}{ Chi-Square Tests } \\
\hline & Value & $\mathrm{df}$ & Asymp. Sig. (2-sided) \\
\hline $\begin{array}{l}\text { Pearson Chi-Square } \\
\text { Likelihood Ratio }\end{array}$ & $\begin{array}{r}7.619^{2} \\
7.961\end{array}$ & $\begin{array}{l}4 \\
4\end{array}$ & $\begin{array}{r}.107 \\
093\end{array}$ \\
\hline Linear-by-Linear Association & $\begin{array}{l}1.961 \\
3.571\end{array}$ & 1 & $\begin{array}{l}.093 \\
.059\end{array}$ \\
\hline $\mathrm{N}$ of Valid Cases & & & \\
\hline
\end{tabular}


Since the chi-square value is more than 5 , the hypothesis is accepted

\section{Findings}

- $95.1 \%$ of the teachers are either graduates or post graduates.

- Over $72 \%$ of the teachers have experience of over 4 years.

- $82 \%$ of the teachers have been using the DCS for less 2 years and totally $96.8 \%$ of the teachers have been using DCS for less than 4 years.

- As per the responses from teachers, DCS helps overall learning/ knowledge delivery to children. Specifically, DCS enables better understanding of concepts, ensures better attention by children and creates excitement about learning amongst children.

- As per responses from teachers, DCS helps in improving overall quality of teaching. Specifically, DCS helps in creating better impact with children, increasing confidence of teachers and enhancing teachers' knowledge.

\section{Conclusion}

The school education in India is currently facing the twin challenge of equipping students for jobs that currently do not exist and enabling teachers to meet the learning needs of today's children. Most of the schools realize that they should transform rapidly by adopting technology to enable better teaching and learning. Schools can no longer simply teach the 3 R's - reading, writing and arithmetic. Children of today need to develop innovation and creative thinking and need to work in a collaborative work environment. Though the children of today are digital natives, they need to adapt technology to acquire knowledge and skills in the ever evolving information-rich digital work and community environment.

For the schools to remain relevant and grow, newer learning approaches need to be implemented.The 'Digital Classroom Solution' used in Indian schools are pre-created by service providers and are mapped to the curriculum of the respective boards. The DCS is used more as a support system for the teachers to ensure effective delivery, rather than as a self-learning tool for the children.

\section{References}

[1]. S. K. Nayak and N. V. Kalyankar (2010).E-Learning Technology for Rural Child Development.International Journal on Computer Science and Engineering, 02(02). 208-212

[2]. D. Aggarwal (2009). Role of E-Learning in a developing country like India.India Com 2009,

[3]. Thakur. A. Kumar and Pallavi (2013). E-Learning: Initiatives in India.Open Journal of Education, 01( 03). 61-63

[4]. D. Mukherjee (2008).E-learning a potential learning solution for rural India- A critical analysis.Conference on Marketing to Rural Consumers IIMK

[5]. S. Anvekar and R. Sugant (2014).E-Learning and Digital Classroom Solutions in Indian Schools: A Study of types and variables for effective adoption.

[6]. International Journal of Information Systems.04(2). 01-06

[7]. Report on The System of Education in India (2006).Nordic Recognition Information Centres

[8]. Indian Education Sector Outlook (2008).CLSA Asia Pacific Markets.

[9]. Emerging Consumer Survey 2012 (2012).Credit Suisse Emerging Market Research Institute.

[10]. S. Kaushal. E\&Y Website.[Online]. Available: http://www.ey.com/IN/en/Industries/Government---Public-Sector/GPS_New-roadsto-learning---perspectives-on-e-learning-in-India

[11]. G S V Advisors.(2012). Eltech digest website.[Online]. Available:http://edtechdigest.wordpress.com/2012/06/19/trends-summaryof-education-sectors/

[12]. Knowledge @ Wharton.(2012). Wharton, University of Pennsylvania website.[Online].Available: http://knowledge.wharton.upenn.edu/article/indias-education-sector-moving-toward-a-digital-future/

[13]. Eindia (2012).[Online]. Available: http://elearning-indya.blogspot.in/2012/10/e-learning-industry-market-potential.html

[14]. ICT Post website.[Online]. Available:http://ictpost.com/2013/11/18/indias-online-education-market-size-is-set-to-grow-to-40billion-by-2017/

[15]. P K Jayadevan.(2012) Nextbigwhat website.[Online]. Available:http://www.nextbigwhat.com/understanding-the-e-learning-marketin-india-297/

[16]. Business Standard website (2012).[Online]. Available:http://www.business-standard.com/article/companies/digital-classroomsmove-deeper-into-india-112052100108_1.html

[17]. CBSE website. [Online] Available: http://164.100.129.152/cbse_aff/welcome.aspx 